\title{
STATE REORGANIZATION STATUTES
}

DuRINg the same depression which developed the elaborate Chandler Act, simpler and more flexible reorganization statutes appeared in a dozen states. ${ }^{1}$ But while federal bankruptcy law has been constantly molded and reshaped by litigation and legislation, the state statutes have continued unexplored. The constitutional knots to be untangled before such laws can safely be invoked seem to have discouraged inquiry into their possible benefits. ' Yet the fact that such statutes are a legislative response to a genuinely felt need in corporate law should inspire searching examination of the barriers which appear to block their use. If the problems raised can be solved, the flexible procedure under these statutes offers to corporations untried possibilities for readjustment of their financial structures.

Almost all of the statutes employ the basic pattern of the Delaware act, ${ }^{3}$ from which a few standard variations have been evolved. Under the Delaware law, the reorganization provision is optional and can become operative only by inclusion in the corporate charter in hacc z'crba. Where it has been added to the charter by amendment, its application is restricted to those who became shareholders or creditors after its adoption. Initiation of proceedings, which may be voluntary or involuntary, is not explicitly conditional on insolvency. Any creditor or stockholder, as well as the corporation, may propose a plan or apply to the court for a hearing on one. At the hearing, participants may urge objections or modifications. If the requisite majority accepts the plan, however, and the court approves it, it becomes binding on all parties, including the corporation. The court is given the necessary powers for enjoining suits pendente lite and for administering and enforcing the plan once it has been approved.

1. 2 Colo. Stat. Ann. (1935) c. 41, $\$ 6(8)$; Del. Rev. Code (1935) c. $65, \$ 2037$ [\$ 5(9)] ; Ilt. Rev. Stat. (1939) c. 32, \$157.90c; Ind. Acts 1939, c. 18, p. 23 ; L.. Ge:i. Star. (Dart. 1939) \&1143; 15 Mich. Stat. ANn. (1937) \$21.4 [\$ 4(3)]; Mrrmi. Stat. (Mason, Supp. 1940) §7492-54; N. M. Stat. ANN. (1929) §32-179; N. Y. Sroce Cosp. LAw (1939) Art. 9, \$§95-99; Onio Gen. Ans. (1937) § \&623-15a; Wasu. Rev. Star. ANN. (Remington, Supp. 1939, 1932) $\$ 3803-58$; W. VA. Cone Aw. (1937) $\S 3018$ [31-1-6(h)].

2. Only one case directly involving one of these statutes has appeared. Wells \& Wade, Inc. v. Unity Orchards Co., 186 Wash. 198, 57 P. (2d) 1050 (1936).

3. Most of these laws are derived from the provision appearing in the Uniform Laws. Uniform Bus. Corp. Act $\$ 59,9$ U. L. A. 102. The original source is probably $\S 153$ of the English Companies Act of 1929. See Palsses, Cosspasy Law (1938) 536.

4. The language of the Delaware statute is essentially as follows: "The Certificate of Incorporation may also contain the following provisions, in haec verba, viz.:

"Whenever a compromise or arrangement is proposed between this corporation and its creditors or any class of them and/or between this corporation and its stockholders or any class of them, any court of equitable jurisdiction . . . may, on the applieation in a summary way of this corporation or of any creditor or stockholder thereof, or on the application of any receiver ... or ... trustees in dissolution . .., order a meeting 
The essence of such statutes is the provision for compelling dissenting creditors to participate in a reorganization approved by the requisite majority of their class. ${ }^{5}$ By eliminating the alternative of cash payments to dissident parties, the acts avoid the twin evils of equity reorganizations: nutisance value auctions and premiums on cash contributions. ${ }^{b}$ This element of compulsion, however, raises at the outset a question of constitutional validity. ${ }^{7}$ The denial of an alternative cash share has been a common basis for invoking the protection of state and federal due process clauses. ${ }^{8}$ It seems clear, however, that no cash shares need be provided where there are no mortgage bondholders. ${ }^{9}$ Moreover, in view of the safeguard provided by the requirement of judicial approval of the plan upon a hearing, the due process objection seems untenable even in the case of secured creditors. ${ }^{10}$

Objections that such statutes violate the constitutional prohibition against state impairment of the obligation of contracts appear at first glance to raise a more substantial obstacle. ${ }^{11}$ But decisions involving state insolvency laws have held that statutes limited in operation to contracts consummated after their enactment are not unconstitutional. ${ }^{12}$ The broad doctrine that all contracts made within the jurisdiction are subject to its laws has sufficed to rebut

of the creditors or class of creditors, and/or of the stockholders or class of stockholders of this corporation, as the case may be, to be summoned in such manner as the said Court directs. If a majority in number representing three-fourths in value of the creclitors or class of creditors, and/or of the stockholders or class of stockholders of this corporation, as the case may be, agree to any compromise or arrangement and to any reorganization of this corporation as consequence of such compromise or arrangement, the said compromise or arrangement and the said reorganization shall, if sanctioned by the court to which such application has been made, be binding on all the creditors or class of creditors, and/or on all the stockholders or class of stockholders, of this corporation, as the case may be, and on this corporation.'

"Jurisdiction is hereby conferred on the Court . . . to administer and enforce . . ." DEL. REv. CODE (1935) c. $65, \S 2037$. The provision against retroactivity is contained in $\S 2035$.

5. See Legis. (1935) 48 HARv. L. REv. 1414.

6. See Colin, Reorganization by Decree (1933) 28 ILL. L. Rev. 225.

7. The constitutional problems are more serious in legislative attempts to bind dissenters than they would be where the same action was taken by equity decree. In the latter case, law is regarded not as being made, but as being interpreted and applicd. See Colin, Reorganization by Decree (1933) 28 IlL. L. Rev. 225.

8. See Comment (1936) 46 Yaze L. J. 116.

9. Phipps v. Chicago, R. I. \& P. Ry., 284 Fed. 945 (C. C. A. 8th, 1922). But cf. Harding v. American Sumatra Tobacco Co., 14 F. (2d) 168 (N. D. Ga. 1926).

10. In the case of mortgage bondholders, the objection seems to rest on contract impairment rather than lack of due process of law. See Detroit Trust Co. v. StormfeltzLoveley Co., 257 Mich. 655, 663, 242 N. W. 227, 230 (1932). For a discussion of this issue, see Rosenberg, Reorganization-The Next Step (1922) 22 Cou. L. Rev. 14; Swaine, Reorganization of Corporations (1927) 27 CoL. L. REv. 901 ; Colin, Reorganization by Decree (1933) 28 ILL. L. Rev. 225.

11. U. S. Const., Art. 1, §10. See (1940) 49 Yale L. J. 1090, n. 6.

12. Baldwin v. Hale, 1 Wall. 223 (U. S. 1863). 
the claims of impairment. ${ }^{13}$ On this theory, therefore, the inclusion of a clause limiting the reorganization statutes to prospective operation ${ }^{14}$ makes possible their validation.

Unfortunately, specific prohibition of retrospective application defers to the contracts clause of the Federal Constitution ${ }^{15}$ at the expense of corporations which may require just such aid to rid themselves of pre-statutory financial burdens. The usefulness of the laws might have been enhanced by omission of this express provision. Those courts which find the provision essential to the statute's validity would doubtless imply the limitation; but it can be maintained that those laws omitting the provision would validly be applicable to obligations previously undertaken, even though such retruactive operation amounted to contract impairment. Reasonable impairment has been sanctioned by the courts with respect to permanent legislation covering specialized enterprises such as banks, ${ }^{16}$ building and loan associations ${ }^{17}$ and insurance companies. ${ }^{18}$ Most often, reorganization statutes of this type have ridden in on the coat-tails of general and comprehensive regulatory systems. ${ }^{13}$ An analogy, however tenuous, can be drawn between such systems and the detailed corporation laws.

Another argument to meet the objection of impairment of contract is the lack of substantial prejudice to the creditor. It has been held that if a creditor is eventually to recover virtually the full amount of his claim, the delny and exposure to further risk suffered meanwhile do not constitute unreasonable impairments of his contract rights. ${ }^{20}$ The same court has also used this reasoning to justify retention of an interest in a bank by stockholders while allowing their release from double liability. Whether this argument must be confined to what, on these facts, the court calls "deferred liquidation," or whether it can be extended to a thoroughgoing reorganization remains an open question. The latter alternative seems indicated, however, by so extreme a modification as release of stockholder liability. Mloreover, the substitution of freely marketable securities for current account debts might well fall within the inflated meaning given "deferred liquidation" by this case. $^{21}$

13. Home Building \& Loan Ass'n v. Blaisdell, 290 U. S. 398 (1934).

14. DEL. REv. CODE (1935) c. 65, § 2035.

15. U. S. Coxst. Art. $1, \S 10$.

16. Paine v. Fox, 172 Tenn. 290, 112 S. W. (2d) 1 (1938); Doty v. Love, 295 U. S. 64 (1935).

17. Pennsylvania v. Williams, 294 U. S. 176 (1934).

18. In re Lawyers Mortgage Company, 277 N. Y. 244, 14 N. E. (2d) 55 (1938).

19. Cf. Pennsylvania v. Williams, 294 U. S. 176 (1934); Penn General Casualty Co. v. Pennsylvania ex rel. Schnader, 294 U. S. 189 (1934).

20. Dunn v. Love, 172 Miss. 342, 155 So. 331 (1934), aff'd, 295 U. S. 64 (1935).

21. Cf. Newman v. Asbury Park \& Ocean Grove Bank, 120 N. J. L. 122, 198 Atl. 236 (1938) ; Paine v. Fox, 172 Tenn. 290, 112 S. W. (2d) 1 (1938). In the former case, depositors were given preferred stock, to be redeemed as the frozen assets were freed. 
Most often, however, legislation affecting existing contracts has been held valid as justified by emergency conditions. ${ }^{22}$ The depression years have swelled the lists of commercial failures to the point at which courts are willing to accept the position of the business cycle as justification for legislative interference with contracts. Statutory reorganization of realty holdings according to the dictates of majority holders, for example, has been upheld in New York. ${ }^{23}$ Since these are but ordinary business corporations, it seems reasonably certain that the emergency doctrine is broad enough to cover reorganization of other business corporations. The coincidence of an economic crisis with the transitional period between enactment of such statutes and discharge of obligations created prior to them should provide all of the necessary elements' for construing the acts as emergency legislation, at least for a limited period, to the extent that retroactivity is necessary.

These issues of constitutional validity are overshadowed in complexity and importance by problems relating to the geographical scope of such legislation. When corporations deal with non-resident creditors or hold property outside the domiciliary state, the effectiveness of the reorganization remedy depends largely on whether it may operate extra-territorially. Delaware corporations, for example, commonly do their business and hold their assets in other states. The Delaware act is thus of little value unless it will bind nonresident creditors in all situations and will extend to all property of the corporation, wherever located. Whether the statute can reach the corporation's out of state business depends on the body of doctrine built on the principle. basic to federalism, that a state cannot give its laws extra-territorial force. ${ }^{24}$ Since foreign creditors who contract with a corporation within the state of its creation are bound by the laws of that state, they seem within the undisputed ambit of the statute. ${ }^{25}$ When the corporation enters into contracts which are made and to be performed in states other than the state of incorporation, however, there is greater doubt concerning the power to readjust such obligations under plans accepted in local courts lacking personal jurisdiction over non-participating foreign creditors.

When asked to give full faith and credit to decrees rendered under such circumstances, a reluctant foreign court might nullify their effect through its power to examine their jurisidictional scope. ${ }^{26}$ State reorganization proceed-

22. Under this doctrine, states may interfere with contracts, but the law thits made must terminate with the emer'rerlcy and must be designed as a reasonable remedy for the specific exigency. See Clark, Emergencies and the Law (1934) 49 PoL. Sar. Q. 268.

23. Neav York Real Proleksty Law (1933) \$§119-123; Schmaling v. Burling, 151 Misc. 47, 269 N. Y.' 'Súppt: 747 (Sup. Ct. 1933) (upholding Shackno Act) ; People by Van Schaick $v$. Title \&: Afortgage Guaranty Co. of Buffalo, 264 N. Y. 69, 190 N. E. 153 (1934) (same).

24. 1 Beale, Conflict of Laws (1935) 52; American Banana Co. v. United Fruit 'Co., 213 U. S. 347 (1909).

25. 2 Beale, Conflict of Laws (1935) 1278.

26. Baker v. Baker Eccles \& Co., 243 IU. S. 394 (1917). 
ings should be classified as "quasi in rem." 27 The administering court exercises control through its possession of the res-ice., the corporate assets or the corporate personalty-and, as in an equity receivership proceeding, obtains jurisdiction over interested parties through service by publication. 28 The generalization is common that an in ron proceeding concludes rights in the res against the whole world. In many cases, however, this effect has been confined within territorial limits on the ground that published service gives notice only within those limits. ${ }^{20}$ Thus, where the res consists only of property in the domiciliary state, the jurisdictional objection takes the form of denying that constructive notice through published service will bind nonresident creditors holding foreign obligations. But inroads have been made upon this doctrine in equity receivership cases. A federal district court in Illinois issued a decree of reorganization barring creditors from participation for failure to file within a certain time. The reorganization decree was given full faith and credit by a Missouri court as a bar to full recovery in a suit by a creditor on a judgment obtained before the reorganization. ${ }^{30}$. Although notice of the court order was personally served on the creditor, the court indicated that service by publication would have sufficed. ${ }^{31}$ In the case of administration of a debtor's estate, then, an order was, in effect, regarded as enforceable outside the jurisdiction of issuance because it was based on in rem proceedings.

Where the corporation owns realty outside the state, the non-resident has available the further objection that such property is not before the court. Even if the decree is binding on him, it merely discharges his personal claim. But where he has obtained a lien on the foreign property, his right may be expunged only if the attached property is part of the res within the court's control. A serious impediment to recognition of such jurisdictional latitude in state reorganizations is created by the policy that a state may administer property within its boundaries according to its own laws. In Clarl: z'. II'illiard,,$^{32}$ the Supreme Court held that the appointment of a liquidator in Iowa under a local statute regulating dissolution of insurance companies must he given full faith and credit in Montana, even as against Montana creditors who were not served with notice. The effect of this interpretation was nullified, however, by the further holding that the dissolution proceedings di $\rfloor$ not embrace Montana property of the Iowa corporation. The distribution of those assets was said to be governed by Montana law. The effect of recognizing the Iowa decree, then, amounted to allowing the liquidator to sue

27. See Glens, Liguidation (1936) 414.

28. St. Louis \& S. F. R. R. v. Spiller, 274 U. S. 304 (1927).

29. GLeNN, loc. cit. supra note 27.

30. Chicago, R. I. \& P. Ry. v. Lincoln Horse \& Mule Comm. Co., 284 Fed. 955 (C. C. A. Sth, 1922). Contra: Northern Pac. Ry. v. Boyd, 228 U. S. 482 (1913).

31. See Chicago, R. I. \& P. Ry. v. Lincoln Horse \& Mule Comm. Co., 224 Fed. 955, 958 (C. C. A. 8th, 1922).

32. Clark v. Williard, 292 U. S. 112 (1934) and 294 U. S. 211 (1935). 
without proceeding through an ancillary receiver. He was subject, however, to the same levies by Montana creditors as could have been made against the corporation before these proceedings were instituted.

In the Williard case, the actual administration proceedings were thus restricted in the name of preserving states' rights. Yet it would appear that the need for expeditiously winding up such specialized enterprises as insurance companies by equitably distributing the loss is far more compelling than the danger to state sovereignty. Inasmuch as this decision circumscribes such proceedings in a manner which largely destroys their effectiveness, acceptance of its general principle seems unwarranted if a position which permits a broader view is equally tenable. It may be argued that since the court established the basic premise that decrees in debtor administration cases looking to reorganization of companies not amenable to bankruptcy must be given full faith and credit, it may impose only jurisclictional limitations. ${ }^{33}$ Accordingly, if the decree is binding at all upon those residing in the recognizing jurisdiction, it should exert upon them the same effect which it exerts upon residents in the jurisdiction of issuance.

Jurisdiction of the required breadth is not new to debtor-relief proceedings. In the determination of venue in bankruptcy cases, administration has long been facilitated by automatic subjection of the debtor's property, wherever located, to the supervision of the administering court. ${ }^{34}$ The same effect is achieved in equity receiverships through ancillary proceedings. Similar jurisdictional inclusiveness in state statutory reorganizations may be derived from the reasoning of Canada Southern Ry. v. Gebhard. ${ }^{35}$ From the premise that the corporation was the creature of the state of incorporation, the Court concluded that the corporation was subject to control by the source from which it drew its powers. So viewed, a court's jurisdiction extends not directly to all the physical assets of the corporation, but to the corporate entity. It is through control over the corporation that a court controls the corporate property, wherever located. Acts which bind the corporation under the laws at home bind it abroad. Correlatively, it was held in the case that a discharge secured according to law in the domiciliary state would discharge the corporation everywhere. In the case of a foreign creditor, the link connecting him with the statutes of the incorporating state is the corporate charter, for "wherever the corporation goes for business, it carries its charter." 30 Where" the reorganization laws are in the form of direct statutory provisions, they become a part of the charter along with all corporation laws of the state. ${ }^{07}$

\footnotetext{
33. Baker v. Baker Eccles \& Co., 242 U. S. 394 (1917).

34. Bankruptcy Act $\S 111,52$ STAT. 884, 11 U. S. C. $\$ 511$ (Supp. 1938) ; 50 STAT. 622 (1937).

35. 109 U. S. 527 (1883).

36. See Canada S. Ry. v. Gebhard, 109 U. S. 527, 538 (1883); Washington-Alaska Bank v. Dexter-Horton Nat. Bank, 263 Fed. 304 (C. C. A. 9th, 1920); Jesson v. Noyes, 245 Fed. 46 (C. C. A. 9th, 1917).

37. See Ballantine, Corporation law \& Practice (1930) 809.
} 
Where they are in the form of powers offered to the corporation at its option, acceptance of that option is indicated by their express inclusion in the charter. In either event, according to the Gcbhard case, the creditor is conclusively presumed to have contracted in contemplation of such laws, since the curporation is necessarily controlled by them. ${ }^{38}$

In view of the flourishing growth of the "bootstrap" doctrine,39 the question of whether the Gebhard view will prevail over that of Clarl: i. II "illiurd may depend largely on the jurisdiction which the administering court finds it is entitled to assume. In a recent case, where the issue of jurisdiction over the subject matter was raised and litigated, one who received notice but failed to appear was bound by the decision. ${ }^{40}$ This principle was further extended to deny collateral attack under similar circumstances, where the issue could have been raised in the original proceedings but was not. 11 These cases seem to indicate that if the administering court is willing to assume control over out-of-state property, its decision on that question must be considered determinative by foreign courts which recognize the decree."

Whether administering courts will take this step depends on the strength of the inhibition against extra-territoriality. If the reluctance to seek to

38. A somewhat weaker alternative theory binding foreign creditors has been spun from the doctrine of constructive notice. To the extent to which notice of the charter's contents will be implied, reorganization provisions included in the charter will become a part of each corporate contract. Attleboro Co. v. Narragansett Elec. Lighting Co., 205 Fed. 895 (D. R. I. 1924) ; Citizens \& Marine Bank of Newport News v. Mason, 2 F. (2d) 352 (C. C. A. 4th, 1924); MicCormick v. Market Bank, 165 U. S. 538 (1897); (1926) 11 CORN. L. Q. 538. While the charter is clearly binding on the stockholders, however, its binding effect on creditors is often limited to those provisions which conventionally appear in corporate charters. Johnson v. Bradley Knitting Co., 228 Wis. 566,280 N. W. 683 (1938) ; In re Interborough Consolidated Corp., 277 Fed. 455 (S. D. N. Y. 1921). Denver Fire Ins. Co. v. McClelland, 9 Colo. 11 (1885); see Comment (1932) 30 Mircu. L. REv. 934. In view of the comparative rarity of these statutes, it might be held that clarrter provisions for reorganization appear too seldom at present to warrant inclusion within that category. Moreover, statutes in a few states provide, in effeet, that the corporate articles shall not give constructive notice. See Ir.. Rer. Star. c. 32, (1939) \$157.8; 1 Dodd and Baker, Cases on Business Organizations (1940) 463, n. 2. One can argue, however, that the limitations in these statutes and cases merely prevent constructive notice of charter provisions outlawing particular contracts, whereas a provision dealing with the rights of creditors in general is within the doctrine.

39. This doctrine means that once a court, after opportunity for litigating the issue, has decided it has jurisdiction, the question is no longer open to collateral attacls. Sae Note (1940) 49 YALE L. J. 959.

40. Stoll v. Gottlieb, 305 U. S. 165 (1938).

41. Chicot County Drainage Dist. v. Baxter State Bank, 60 Sup. Ct. 317 (U. S. 1940), 49 Y YLE L. J. 959.

42. Accordingly, a non-resident creditor who obtained a lien on property outside the state before institution of reorganization proceedings may preserve his lien only by direct appeal of this jurisdictional point. Since he must be a participant in the original proceedings and must perfect his appeal within a limited time, the risl: that such reurganization proceedings might be upset is considerably diminished. 
extend laws beyond state lines springs solely from considerations of federalism, it is now clear that strict territoriality is by no means demanded. In recent workmen's compensation cases, the same problem of extra-territoriality arose when employees, injured outside the state in which the contract for work was made, brought suit in the state of contracting. With full recognition that the laws were being enforced beyond state lines, the courts generally granted compensation under their own statutes. ${ }^{43}$ Where the law was optional rather than compulsory, some courts placed the recovery on a contractial level, reasoning that the parties included the law in their negotiations. More realistic courts, however, refused even vestigial acknowledgment of this technical argument. Their decisions were set on the broader base of refusing to restrict the operation of a law which the state has found socially necessary.4 Further conviction is added by the Supreme Court's latest word on the subject. ${ }^{45}$ A Virginia statute regulating the writing of insurance policies wats upheld even though it resulted in the imposition of greater cost on foreign corporations contracting outside the state. In justification, the Court declared that the mere fact that state action might have extra-territorial repercussions which were against avowed state policies was of no judicial significance so long as the action taken by the state was within its constitutional powers.

It may be argued, of course, that application of the full faith and credit clause to reorganization statutes may be denied in the name of local policy. The constitutional requirement is subject to a well established exception where recognition of the foreign statute on which the cause of action is based would conflict with the public policy of the recognizing forum..$^{40}$ In a recent case, for example, a Massachusetts employee was injured in California while working under a contract made in Massachusetts with an employer of the latter state. ${ }^{47}$ In the suit in California for compensation, an attempt to import the Massachusetts statute under the full faith and credit clause was frustrated by the California court. Its argument was that application of the Massachusetts statute denied effect to the California act, and, to the extent that the two acts differed, would nullify the duly authorized expression of California policy. In maintaining this position, the court recognized that the Massachusetts court

43. See Hall, Extraterritorial Application of Workmen's Compensation Acts (1935) 13 Chi-Kent Rev. 114.

44. Compare Crane v. Leonard, Crossette \& Riley, 214 Mich. 218, 183 N. W. 204 (1921) and Hulswit v. Escanaba Mfg. Co., 218 Mich. 331, 188 N. W. 411 (1922), with Anderson v. Miller Scrap Iron Co., 169 Wis. 106, 116, 170 N. W. 275, 278 (1919) and McGuire v. Phelan-Shirley Co., 111 Neb. 609, 612, 197 N. W. 615, 616 (1924). In the first two cases, the holding is based on the law of the place of contracting and is framed in "conflicts" language. In the third case, there is a perfunctory argument in these terms, but reliance is placed mainly on public policy. The last case completely abandons the technical argument for the public policy basis.

45. Osborn v. Ozlin, 8 U. S. L. WeEK 677 (U. S. 1940).

46. See Nussbaum, Public Policy in Conflict of Lazes (1940) 49 Yale L. J. 1027.

47. Pacific Employers Ins. Co. v. Industrial Accident Comm. of Cal., 306 U. S. 493 (1939). 
would have regarded its own statute as controlling if suit had been brought in that state. The same attitude is evinced toward revenue ${ }^{48}$ and penal ${ }^{4 a}$ law's for a somewhat different reason. One state will ordinarily ignore criminal convictions in another, and its courts will generally withlold jusgments of liability for the taxes of another.jo The reluctance to accept jurisdiction over such questions is engendered by a desire to aroid possible embarrassment in interpreting the obligations owed to another sovereign by the latter's citizens. Combining the desire to favor local policy with the antipathy for foreign penalties, courts in the past refused to recognize insolvency proceedings in another state. ${ }^{51}$ If the reorganization statutes are regarded as essentially insolvency laws, this attitude might be extended to them.

Recent decisions, however, indicate a tendency to constrict this exception. In the field of taxation, dicta of a recent case leave open the question of whether judgment in an original suit must be rendered by one state on the basis of a taxing statute of another.52 But the case holds that, regardless of the answer to that question, suit on a tax judgment obtained in the legislating state must be entertained in the foreign court. ${ }^{.3}$ Likewise, criminal convictions in other states have been recognized for some purposes. ${ }^{\text {st }}$ On the whole money judgments are given full faith and credit regardless of the reeognizing forum's disapproval of their underlying cause of action. ${ }^{55}$

Moreover, legislatures have contrived to combat analogy to insolvency statutes by withdrawing the reorganization laws from the atmospliere of debtor-relief measures and embedding them in corporation laws. Unsupported by a fundamental difference, however, this disguise will not set the new acts apart from the early insolvency laws. The discovery of a sufficiently substantial distinction depends on recognition of the corporation laws as a unified regulatory system. Under this view, the reorganization statutes represent a process of readjustment of financial structure rather than a system for dis-

48. See Freeze, Extra-territorial Enforement of Recenue Laus (1938) 23 WaSE. U. L. Q. 321.

49. Wisconsin v. Pelican Ins. Co., 127 U. S. 265 (18Ss); see Freeze, loc. cit. stspra note 48 .

50. See Freeze, loc. cit. supra note 48.

51. Denny v. Bennett, 128 U. S. 489 (188S) ; Baldwin v. Hale, 1 WVall. 223 (U. S. 1863) ; Cook v. Moffat, 5 How. 295 (U. S. 1847); Satterthwaite v. Abercrombie, 24 Fed. 543 (C. C. S. D. N. Y. 1885) ; Bean v. Loryea, 81 Cal. 151, 22 Pac. 513 (18S9). See Bailey, Discharge in Insolvency and Its Effect on Non-Residents (1\$93) 6 HAsv. L. Ra. 349 for a contemporary discussion of this problem.

52. See Milwaukee County v. White, 296 U. S. 268,275 (1935).

53. Milwaukee County v. White, 296 U. S. 268 (1935).

54. State $e x$ rel. Salisbury v. Vogel, 65 N. D. 137, 256 N. WW. 404 (1934); State ex rel. Anderson v. Fousek, 91 MLont. 44S, S P. (2d) 791 (1932). In these cases foreign convictions availed to rule out candidates for public office under local disqualification statutes.

55. Restatearent, Conflict of Laws (1934) $\$ 446$. See Milwaukee County v. White, 296 U. S. 268, 275 (1935). 
tributing assets to creditors. There is no basis for deriving from a process of this nature the implications of disgrace or of penalty inherent in exposure of an individual to insolvency proceedings.

The reclassification of reorganization statutes as corporation laws assumes greater significance as a key to the problems raised by conflict with federal bankruptcy legislation. The theory of the paramountcy of federal bankruptcy legislation requires, broadly, that state laws within a field entered by Congress remain in abeyance while the federal law is in force. ${ }^{50}$ If these statutes are to remain active in the face of the Federal Bankruptcy Act, the most must be made of gaps in this doctrine. That these gaps are various and frequently available is the single generalization clearly apparent from the cases in this field. The most effective techniques for defeating the formula are the "blind spot" theory based on omissions and exclusions from the Bankruptcy Act, and definitional arguments. The success of the latter has decreased with the gradual widening of the bankruptcy power. In recent years, the area of bankruptcy law has been defined to include no less than "the subject of relations between an insolvent or non-paying debtor and his creditors extending to its or their relief." 57 Argument that state reorganization statutes restricted to insolvency are essentially part of a system of corporate regulation or that they operate on a contractual level is manifestly unconvincing unless the court can be persuaded to overlook this definition. But even this inclusive description of the bankruptcy power need not create conflict between federal and state legislation where no explicit requirement of insolvency appears in the state law. The latter type of statute may be freely invoked by a corporation which not only is solvent but contemplates no defatult in its obligations. A corporation, for example, with prevision of future conditions might find advisable present changes in its debt structure. Similarly, the statute might be used to modify inter-class relationships between stockholders. ${ }^{58}$

The remaining limitations on the state reorganization statutes relate to procedure rather than validity. In initiating proceedings, greatest latitude is allowed under the Delaware act. Creditor and debtor alike may propose a plan. Moreover, regardless of who presented the scheme, either class may apply to a court for a hearing on it. Insofar as such freedom permits involuntary proceedings, the statute approaches nearer to the bankruptcy borderline. Counterbalancing this risk, however, is the efficiency gained by allowing the

56. See (1940) 49 YALE L. J. 1090.

57. See Continental Illinois Nat. Bank \& Trust Co. v. Chicago, R. I. \& P. Ry., 294 U. S. 648, 673 (1935) ; In re Merced Irrigation Dist., 25 F. Supp. 981, 987 (S. D. Cal. 1939).

58. But cf. First National Bank in Albuquerque v. Robinson, 107 F. (2d) 50 (C. C. A. 10th, 1939). This case invalidated an entire system of New Mexico "insolvency" laws among which was a provision allowing reorganization, but limiting it to readjustment of stockholding interests. In view of the unquestioned power to validate such changes by legislation regulating amendment of corporate charters, it would appear that this section of the statute would not have been suspended if it had been separately consiclered. 
proceedings to gather impetus from a number of sources. The advantage becomes clearer in the light of the restrictions imposed by the Colorado act, ${ }^{59}$ which allows the corporation alone to propose a plan. Once the arrangement is presented, proceedings can be advanced by creditors or stockholders to the stage of a hearing only if they apply to the court in respective majorities. With the initiative in the reorganization thus largely in the hands of the management, the procedure is exposed to unnecessary delay. Even where the corporation is anxious to work out an arrangement, it can use the opportunity implicit in this type of statute to draw out the proceedings within limits which it deems prudent, in the hope that a change in business conditions will alleviate the critical pressure. Having set rumors of reorganization afloat, the management can retreat behind its exclusive statutory power to promulgate plans and work out an arrangement at a more leisurely pace than collaboration with creditors would allow. Before the impatience of the creditors overcomes their inertia, the management can offer its plan in reliance on application to the court as a further opportunity for delay. By leaving this step to the creditors, the corporation gains the time that will pass before the necessary majority is collected.

The purpose of vesting power to offer plans in the corporation's hands is apparently to make these proceedings voluntary. The reasons for requiring a majority for creditor initiative, however, are less evident. If the requirement was aimed at augmenting the chances of a brief and successful courtroom session by assuring a confidence-inspiring minimum of rotes beforehand, it defeats the essential purpose of the hearing - i.c., judicial control - by necessitating an informal preliminary bargaining process with no judicial safeguards. Without sacrificing the voluntary nature of the remedy, greater efficiency and more effective judicial supervision can be achieved by rephrasing this provision in the language of the Minnesota act. ${ }^{\text {cI }}$ Under that law, anyone may propose a plan, but only the corporation, its receiver, or its liquidator may bring the plan to court. Chances for putting through the reorganization are enhanced by creditor participation in the drafting process, while delay is minimized by placing the burden of proceeding to court on the corporation. Since the management has exclusive power to take this next step, it will be subjected to creditor pressure from the moment the plan is proposed.

Before the plan may be heard in court, notice as prescribed by the court must be sent to all the interested parties. Here the elimination of alternative cash shares raises an important due process issue. Since the creditor's claim is being scaled down and perhaps rendered illiquid, courts will carefully scrutinize the manner in which he was notified of these proceedings. Service by publication may not be enough. The "jurisdictional" question becomes a constitutional one of due process.

59. Colo. Stat. Ans. (1935) c. 41, $\$ 6(8)$.

60. Compare Minn. Stat. (Mason, Supp. 1940) $\$ 7492-54$ with the Delaware Act quoted in note 4 supra. 
Once the plan has been heard in court, it must be voted on. It is at this point that the essential function of the statute comes into play. Under its authority, the requisite percentage of favorable votes will bind the minority to acceptance of the plan. Typical wording of the voting provision appears in the Delaware law. ${ }^{61}$ Whether by design or by fortuitous draftsmanship, the legislators have extended minority stockholders unusual protection against the management. It will be noted that the prescribed vote is phrased not only in terms of three-fourths of the value of all the shares, a quantity which might well be embraced in one holding, but also as a majority of the number of shareholders. That this device may be more than a weapon of defense is apparent. By clubbing together, minority interests might defeat the statute's primary purpose of eliminating opportunistic obstructionism. While the mijority might combat this by splitting their shares among dummy holders, it is questionable whether a court of equity would approve tactics which might shortly degenerate into a contest of fractionation. This difficulty is easily avoided by providing that the stockholder vote be in terms of voting power of the shares. ${ }^{62}$

A further problem is provided by the introduction of value as a standard. The language of the statutes does not make clear whether the vote is to be by classes where the arrangement affects several classes of stock. ${ }^{03}$ If sectritics of different par values vote as one group, complex possibilities for maneuvering are created. Assuming a corporation-with 2,000 shares of preferred stock, par 100, and 10,000 shares of common stock, par 10, the preferred stockholders could dominate the reorganization by securing the support of $25 \%$ of the common stock. The more the management trades on the equity, ${ }^{64}$ the greater this leverage will be. A point can be reached where it will be profitable for the preferred stockholders to buy up the necessary percentage of common stock and force through a plan virtually extinguishing that class. Creditor support of the plan will obviously increase with the curtailment of common stock rights. Faced with a reassuring vote, the supervising court might fail to appreciate the degree to which such leverage was being exerted.

To the extent that the brunt of the reorganization is thus made to fall on the common stock, this type of provision leads to a result approximating the

61. See note 4 supra.

62. Minn. Stat. (Mason, Supp. 1940) § 7492-54.

63. See note 4 stipra.

64. "Trading on the equity" is a term used to denote issuance of securities bearing a fixed return which the management hopes will be less than the return on the capital which those securities represent. The excess so earned is available for common stock dividends. For example, if a corporation issues $\$ 100,000$ of $6 \%$ preferred and $\$ 100,000$ of common stock and earns $10 \%$ on all invested capital, $\$ 14,000$ of its earnings of $\$ 20,000$ are available for dividends on common stock. The common stock yield is thus $14 \%$, even though the corporation earns only $10 \%$. 
effects of the Boyd doctrine. ${ }^{65}$ Under the Minnesota statute, on the other hand, the same failure to clarify the voting procedure produces exactly the opposite effect. Since that statute is phrased in terms of voting power, the leverage lies with the issue having the largest number of shares, which would probably be the common stock.

The extent of judicial supervision of these steps is suggested only vaguely by the stipulation that plans are subject to approval by the court. From the paucity of case material it is as yet impossible to derive any limiting generalization regarding standards which the courts will adopt. New York has clearly adopted the Boyd doctrine in its administration of the realty reorganization laws. ${ }^{66}$ While the only other case in point ${ }^{67}$ seens to leave room for inference that these statutes might be used as specific authority for evading that doctrine, the Supreme Court's present attitude malies this development unlikely. In view of the strong expression of policy in recent applications of the principle, ${ }^{88}$ it is conceivable that the Boyd doctrine may become a yardstick for measuring the constitutionality of reorganization proceedings in terms of the due process clause.

The problems and pitfalls of these statutes naturally narrow their sphere of usefulness. Reorganizations of the sort which they can offer would be attractive to a large corporation as a means for eluding the zealous watchfulness of the SEC. ${ }^{69}$ But the extent to which large firms engage in interstate dealings exposes them to numerous suits collaterally attacking such arrangements on any of the grounds discussed above. It is true that courts have indicated an increasing reluctance to overthrow settlements that have otherwise come to fruition. ${ }^{70}$ It is likewise evident that risk of supersession by

65. Northern Pac. Ry. v. Boyd, 22S U. S. 482 (1913); Case v. Los Angeles Lumber Products Co., 60 Sup. Ct. 1 (U. S. 1939). For a discussion of the doctrine of strict priority, see (1940) 49 Yale L. J. 1099.

66. Chase National Bank v. 10 East 40th St. Corp., 238 App. Div. 370, 264 N. Y. Supp. 882 (1st Dep't 1933) ; Rice v. Pounds, 153 Misc. 226, 274 N. Y. Supp. 637 (Sup. Ct. 1934) ; Clinton Trust Co. v. 142-144 Joralemon St. Corp., 237 App. Div. 789, 263 N. Y. Supp. 359 (2d Dep't 1933).

67. Wells \& Wade, Inc. v. Unity Orchards Co., 186 Wash. 198, 57 P. (2d) 1050 (1936).

68. Case v. Las Angeles Lumber Products Co., 60 Sup. Ct. 1 (U. S. 1939); Securities \& Exchange Comm. v. United States Realty \& Improvement Co., 8 U. S. L. WEEE 925 (U. S. 1940).

69. 52 Stat. 890, 11 U. S. C. $\$ \$ 572-574$ (Supp. 1938).

70. Thus, collateral attack was denied where the attacking creditor could have filed an involuntary petition within the statutory period but instead sought to obtain a preference through garnishment of the fund assigned under the state law. Boese v. King, 103 U. S. 379 (1883). In a later case, an attacking creditor failed even though he could not have filed an involuntary petition. Johnson v. Star, 287 U. S. 527 (1933). The development of the "bootstrap" doctrine illustrates a further extension of this attitude. Sce note 39 supra. 
federal proceedings ${ }^{71}$ dwindles as they increase in complexity and expense. ${ }^{72}$ Nevertheless, the number of possible suits by non-resident dissidents alone would probably overshadow the benefits from resort to these statutes where federal proceedings were available. In a solvent corporation, however, these statutes suggest a useful means for modifying stockholders' ${ }^{\prime 3}$ rights or for revising the debt structure where ordinary methods of refunding are unavailable or infeasible. ${ }^{74}$

The statutes seem better designed to meet the needs of small, local enterprises whose property is generally within one state. When some ordinary business misfortune causes financial stringency, it is not only to their best interests, but to those of the community as well, that they be provided with a means of reducing the pressure without losing their grip on the tangibles and intangibles which constitute a going concern. Resort to the liquidative process of bankruptcy would mean loss of the corporate assets and acquisition of the unpleasant taint of "bankrupt." Chapter XI offers the only comparable remedy, but its desirability is diminished by its inapplicability to secured claims.

In view of the problems impeding their growth, there seems little likelihood that these statutes will mushroom into systems competing with the Bankruptcy Act. Uniformity of administration of debtor-creditor relations is consequently in little danger. From the practical legislator's point of view, moreover, an opportunity for small-scale experimentation is provicled that will test the feasibility of possible innovations in the federal law. Meanwhile, the use of these statutes within their restricted spheres would add to the entire system of debtor-creditor supervision the flexibility required for meeting distinctly local problems.

71. See (1940) 49 YALE L. J. 1090, 1098 for the argument that the Bankruptcy Act recognizes the validity of state proceedings. Cf. Gallagher v. Keystone Realty Holding Co., 333 Pa. Rep. 9, 3 A. (2d) 426 (1939).

72. As to the cost of reorganization, see Referee's opinion, Chase National Bank v. 10 East 40th St. Corp., N. Y. L. J., Oct. 2, 1933, p. 1, col. 7. The reorganization expenses were $\$ 346,640.38$. Appellant's brief (p. 48) estimates the average cost of reorganization under the Schackno Act to be $\$ 3,000$.

The risk of supersession is further decreased by the jurisdictional limitations of Chapters X and XI, e.g., the insolvency requirements and limitations on the scope of the plans with respect to securities affected. See also Rostow and Cutler, Competing Systems of Corporate Reorganization (1939) 48 YALE L. J. 1334.

73. The modification of stockholders' rights is ordinarily possible through charter amendment; it is, accordingly, difficult to see the value of the New Mexico and Ohio statutes, which do not extend to creditors but are limited to changes within the classes of stock.

74. The problems facing solvent corporations are well discussed by Sargent \& Zelkowich, Reorganizing "Solvent" Corporations (1934) 29 ILL. L. REv. 137. 